\section{Australian government plans Internet censorship}

The government in Australia is proposing to introduce compulsory blocks on certain websites for everyone accessing the Internet from inside the country, and to trial these filters before the end of the year.

Stephen Conroy, the communications minister, said in a Senate hearing in late October that the government proposes a two-tier system of restrictions as part of its Aus $\$ 44.2$ million (US\$29.8 million) cybersafety plan. The first tier of filters would be compulsory, and would force all Internet service providers to block Australians' access to illegal websites, including overseas online gambling sites, according to a report in the Sydney Morning Herald. A second tier is planned as an optional set of additional filters that would make it impossible to access material deemed unsuitable for children.

Religious organizations such as the Australian Christian Lobby support the proposals. But critics worry about the ease with which the government might exand the list of blocked sites. They claim that access will not be effectively cut off to illegal content such as child pornography because peer-to-peer file-sharing networks will remain unimpeded. The System Administrators Guild of Australia says the planned filters will increase the price and reduce the speed of Internet access.

\section{Oil company blamed for mud-volcano eruption}

After more than two years of debate, a vote of 74 Earth scientists at last week's American Association of Petroleum Geologists conference blamed an Indonesian oil company for creating a mud volcano.

Mud has been spewing from a former rice paddy in Sidoarjo in East Java since 29 May

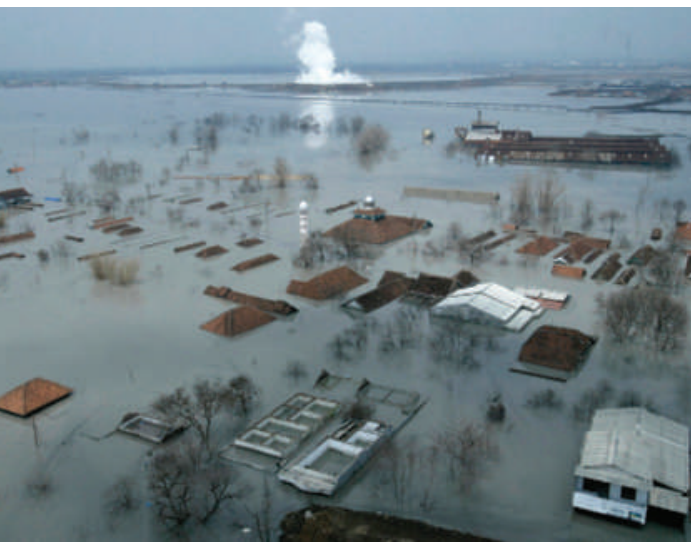

The Sidoarjo mud volcano has caused widespread devastation.

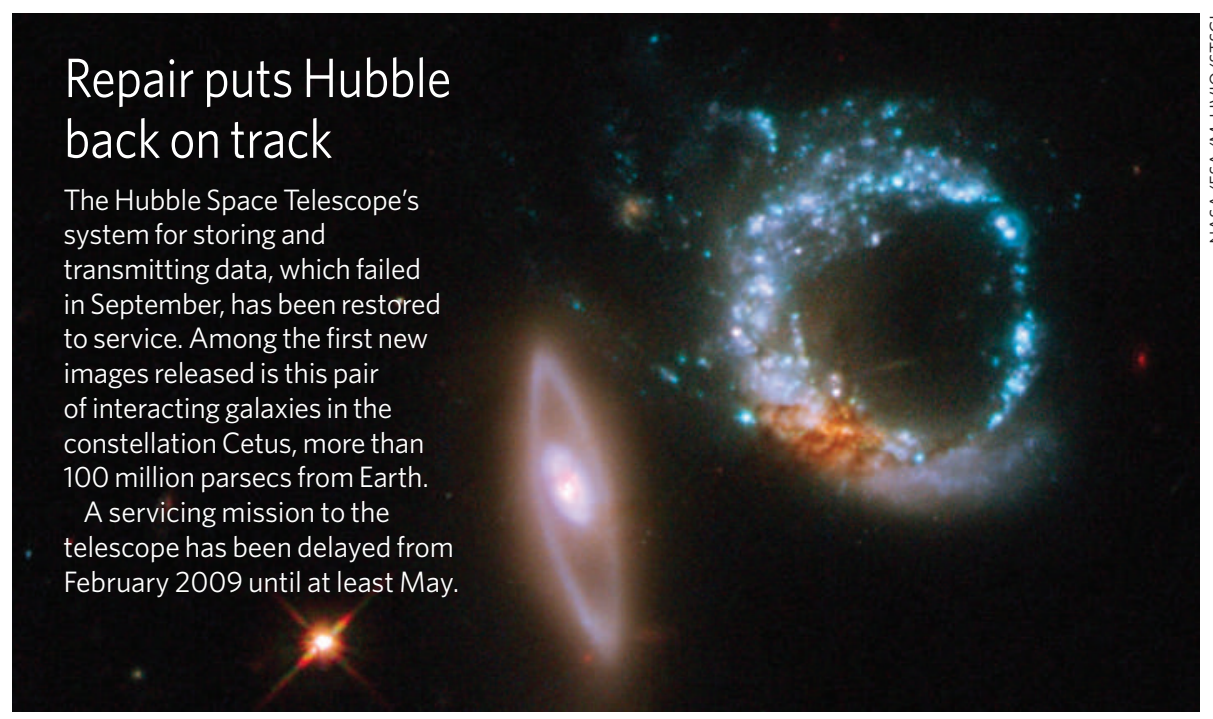

2006 (see Nature 445, 812-815; 2007), and the question of who will pay for the cleanup hangs on what caused the disaster. PT Lapindo Brantas, the oil company, says the cause was an earthquake that had struck two days beforehand.

But the majority of scientists attending the meeting in Cape Town, South Africa, voted that the tremors had hit too far away for them to be responsible. Some researchers presented data showing that the pressure created by the company's drilling was sufficient to break a path for deep mud to rupture the surface.

\section{Help promised for troubled maker of electric car}

Elon Musk, chief executive of electric-car company Tesla Motors, has denied rumours that the company is about to go bust.

In an interview on 31 October with Reuters news agency, Musk admitted that Tesla Motors, which has just started making its environmentally friendly sports cars, has only US\$9 million in the bank, despite taking deposits on 1,200 roadsters costing $\$ 109,000$ each. The interview was sparked by comments posted on the Valleywag blog, a Silicon Valley gossip site, suggesting that Tesla would not be able to deliver the promised cars.

On 2 November, Tesla, which is based in San Carlos, California, announced that several unnamed investors have promised $\$ 40$ million to help prop up the firm.

\section{Google settles suit over copyright of scanned books}

Google has agreed to pay US\$125 million to settle a class action suit brought by the Authors Guild and several publishing companies in the United States against its Google Book Search service. Authors and publishers will also get a cut of the future revenues that the service generates.

In return, the 28 October deal permits Google's US readers to see fuller previews instead of small snippets of copyrighted books. Libraries will be able to subscribe, which will allow their patrons to read the contents of entire books over the Internet. Text and data-mining researchers will also have the right to run computational queries in a 'research corpus' copy of the entire Google Book text and image database.

Google has already scanned into the database more than 7 million titles from university research collections and partner publishers.

\section{Crop research a target of international investment}

The US National Science Foundation (NSF) has awarded nearly US\$60 million in grants for plant-genome science, most of which will go towards research in crop species.

On 27 October, the NSF assigned $\$ 3.2$ million for work probing how genetic and biochemical pathways help Medicago truncatula - a model organism for legume research - adapt to high-salinity conditions. That project is being led by scientists at the University of Southern California. Another of the 20 grants was given to researchers at Pennsylvania State University in University Park. The team received $\$ 4.8$ million to look into the genes that function during the growth of maize (corn) shoots, which is regulated by the hormone auxin.

And in Britain, the government's science think tank, the Foresight Programme, wants to know how to feed nine billion people equitably, healthily and sustainably. It is launching a study into what the world's farming needs might be in 2050, the findings for which should be available in 2010 . 